\title{
Meaning Pedagogy as a Vector for the Development of Vocation- al Teacher's Self-Efficacy in Integrative Environment
}

\author{
Ushakov A.A ${ }^{1}$., Sazhina N.M. ${ }^{2}$, Sinitsyn Yu.N. ${ }^{3}$, Khentonen A.G. ${ }^{4}$, Grebennikov O.V. ${ }^{5}$, Fialko A.I. ${ }^{6}$ \\ Kuban State University \\ *Corresponding author E-mail:
}

\begin{abstract}
The relevance of this work is due to the fact that in the context of globalization of education and integration processes in educational systems, the requirements to teachers' professionalism and their personal traits increase. The main resource for improving the quality of education is teachers motivated for continuous professional development. Value and meaning-wise attitude to teaching profession defines self-efficacy as confidence in their professional and pedagogical actions. The processes of purposeful formation and development of selfefficacy in the integrative environment are the most important instruments to improve teacher's professionalism. In this regard, this paper reveals the essence, content and structural components of self-efficacy, and identifies the mechanisms of its development in the modern integrative environment in terms of meaning pedagogy. The leading approach to the study is the integrative-systematic approach. It considers the development of self-efficacy on the basis of meaning pedagogy in the conditions of integration of educational environments. The pilot study (self-efficacy testing) engaged 122 university teachers under the age of 35 working as a teacher from 3 to 5 years. The paper defines the essence of the teacher's self-efficacy and its relationship with meaning pedagogy. The study identified the following structural components of teacher's self-efficacy in the modern integrative environment: understanding the professional and pedagogical goal, meaning and results of professional and pedagogical activity, control loci "I" and "professional and pedagogical activity", and meaningfulness of professional and pedagogical activity as a generalized component of self-efficacy. The results of the pilot study showed the tutoring support for the development of vocational teachers' self-efficacy is necessary. The paper presents the technology of developing teacher's self-efficacy in integrative environment. This technology is based on the tracing individual development as the routes to the future, points of bifurcation. One of the possible directions is selected while passing these points. The research results define new vectors of self-efficacy development based on life-purpose guidelines, significantly expand the theoretical understanding of development and self-development of teachers in the modern integrative educational macro-environment. The paper is interesting for organizing the tutoring support for the development of vocational teachers' self-efficacy. It can also be used in the system of continuous education.
\end{abstract}

Keywords: meaning pedagogy, teacher's self-efficacy, integrative-systemic approach, integrative environment, development technology.

\section{Introduction}

The main resource of socio-economic reforms and introducing the innovative technologies in various industries is specialists motivated for continuous professional improvement and selfdevelopment. Modern teachers should solve professional problems quickly and creatively; they should have the ability to determine and implement the priorities of their activities and ways to improve it on the basis of self-assessment. Competent specialists through perceiving the signals of society see and use the opportunities available. Integration processes taking place in educational environments significantly expand the opportunities for professionally developing macro-environment outside the specific educational organizations. The relevance of the research is due to the increasing requirements to professionalism of teachers and their personal traits, which determines the need for continuous selfimprovement based on the meanings of professional and pedagogical activity (Fartash et al., 2018; Davoudi et al., 2018).

The most important tools to improve the professionalism are purposeful formation and development of self-efficacy in the modern integrative environment. Vocational teachers themselves create a developing environment, integrating its resources into personally valuable meanings.

The aim of the study is to reveal the essence, content and structural components of self-efficacy, to identify the mechanisms of its development in the modern integrative environment in terms of meaning pedagogy.

The concept of meaning appeared in philosophy, primarily from existentialism, from the works of Camus and J. P. Sartre. In his book "Being and Nothingness", Sartre writes a that the meaning is a phenomenon of existence, the meaning itself possesses existance.

The original historical context, which gave meaning the status of scientific concept, was the study of text comprehension. The first paradigm was hermeneutics, which appeared as a science of interpreting the hidden meanings; it gradually became a doctrine in a broader context. The second historical context was the phenomenological analysis of consciousness. According to E. Husserl, we see not the world or its part, but its "meaning". The source that ascribes meaning to things is consciousness, an ordered experience. It is our existence and the life of our consciousness that give meaning to the world. Husserl identifies two directions of phenomenological analysis: noetic, or describing the act of experiencing, and noematic, or describing what is experienced. Noesis re- 
fers to the orientation of consciousness to the object, noema is the object itself as the bearer of meaning. The most detailed analysis of experience in these terms is given by Husserl's follower G Shpet. Assuming that Husserl's concepts of "sense" and "meaning" are equivalent, Shpet justifies their difference: the meaning of the phenomenon is in revealing the object in its existence. Shpet introduced the concept of" inner meaning", through which people have a sense of their place in the world. The third context is due to the existential meaning of human existence. P. Tillich in his most famous work "Courage to be" notes that people are human beings only because of their ability to understand and shape their world and themselves according to the meanings and values. Man lives "inside" of meanings, within the thing that has relevance. The loss of meaning is caused by the loss of the spiritual center, and it provokes a specific anxiety. The concept of $\mathrm{M}$. M. Bakhtin considers the meaning to be the scope of culturally entrenched meanings transcendent to individual existence. Finally, the fourth context of using the concept of meaning implies the problem of the meaning of human actions and other non-verbal manifestations.

The concept of meaning as a life task is developed by V. Frankl. His teaching has three parts: the doctrine of striving for meaning, the doctrine of the meaning of life, and the doctrine of free will. Frankl regards striving for search and realization of the meaning of one's life as innate motivation tendency, inherent in all people. The lack of meaning gives rise to a condition, which Frankl calls existential vacuum, which is the cause of noogenic neuroses. Thus, a person seeks meaning and feels frustrated or vacuum if that aspiration remains non-realized.

The Russian dictionary of S. I. Ozhegov provides several lexical meanings of the word "meaning: inner content, the meaning of something perceived by the mind; the purpose, the reasonable basis; the same as the mind. Meaning is the ideal content, the idea, the essence, purpose, and ultimate meaning of something; the holistic content of any statement, not reducible to the meanings of its constituent parts and elements, but itself determining these values. Thus, the meaning is related to the idea of internal (ideal) content that displays the purpose, the ultimate meaning of anything. This is the goal, the subject of aspiration, what is to be done.

S. L. Rubinstein wrote: "People who have chosen the profession of teacher or doctor for the sake of money, power or prestige, not for the sake of love for children and compassion for the sick, should not be surprised if their work seems tedious and poorly paid to them; they will get pure disappointment". Pedagogical idealism is the axiological basis of the work of a true teacher. "Deep down, we crave useful, creative work that gives food to the mind and work for the hands - the work that meets our most cherished aspirations. The rhythm of the labor, freely chosen and made with pleasure, is the secret of understanding life and its purpose" (Rubinstein, 1976).

N. V. Kuz'mina emphasizes that work is efficient only if the worker possesses the sense of professional activity: "Adult personality usually looks for new, deeper or individual meanings of their activities (life, labor). The totality of meanings forms a system of personal spiritual values, personal professional mentality, and individual professional credo. It is important to have meaningmaking creativity, i.e. the ability to "scoop out" new meanings from his profession" (Kuz'mina, 1985). If the level of meaningmaking creativity is low, the teacher gives up when facing the slightest difficulty. One of the psychological features of the creative teacher is life-purpose orientations. "It is important to realize the essence, importance and objectives of own teaching activities, its goals, to constantly correlate the current pedagogical tasks with prospects. If not, the teacher can be a good worker, but will never grow to the level of creativity" (Kan-Kalik \& Nikandrov, 1990). Thus, the meaning pedagogy is a system of views, knowledge and ideas about the meaning of professional and pedagogical activity and the teacher's place in modern society.

Meaning pedagogy is the main vector determining the development of vocational teachers' self-efficacy. Self-efficacy is a cate- gory of "self" system of psychological concepts (selfdevelopment, self-regulation, self-organization, self-management, self-education, and others). These concepts mean modern universal competencies. The "self" concept brings the following meanings into complex concepts: the action on itself; involuntary action, made on one's own. "Self" group of concepts can be considered as a single system that combines the psychological content of the homogeneous concept with two common features: the values they describe have a psychological nature. The subject and the object of the described activity belong to the same system (Tastan et al., 2018).

In its broad sense, self-efficacy as an integral part of the selfsystem. It is confidence in one's own ability to organize and carry out the actions necessary to resolve the presupposed situations. This definition of self-efficacy was given by A. Bandura, the founder of the theory of social learning. In other words, selfefficacy is a confidence in their ability to succeed in a given situation. This concept, on the basis of the semantic analysis, can be described differently: as inner conviction or self-confidence; internal mechanism of activity regulation; form of subjectivity manifestation; component of self-consciousness (T. V. Timofeeva, 2015).

Highly efficient specialists consider complex problems as tasks, which would surely be solved, show deep interest in the performed activity, feel commitment to the interests and the business. On the contrary, teachers with low self-efficacy avoid complex tasks and believe that their solution goes beyond the limits of opportunities; they quickly lose confidence in their abilities. Selfefficacy is a significant personal trait of a teacher initiating the continuous educational movement. The study of self-efficacy in the professional pedagogical activity is crucial, for it is the idea of their own competence, and not the skills, personal qualities and abilities themselves, is a necessary motivational skill that determines human behavior, their desire for continuous education and the degree of perseverance in the performance of specific professional actions (S.N. Gonchar, 2015). Personal competence is a holistic, dynamic, multi-component formation, containing teachers' opinion on possessing professionally important qualities and confidence that they would be able to use these qualities to achieve success in their professional activities (F. A. Baybanova, 2014).

Thus, teacher's self-efficacy is a personal trait, manifested in the inner conviction or confidence in personal professional and pedagogical actions. Unlike the objective knowledge, confidence in one's abilities is subjective and personal, it depends on the teacher and their efforts to achieve professional and pedagogical tasks. The main directions of teachers' self-efficacy development are determined based on the meanings of professional activity.

The development of this trait on the basis of meaning pedagogy is significantly transformed in modern integrative environment. In classical pedagogy, environment is a source of human development and their subjectivity (L. S. Vygotsky). According to the theory of education of A. S. Makarenko, environment, which is organized in the most profitable way, develops best. In this case, there is always a mutual influence of subject and environment. From the viewpoint of the theory of modern self-development, teachers' educational environment is a set of external incentives for self-educational activities, meaningful sources of formation of professional and personal attitude, and communicative opportunities in teaching activity.

Internet communities as a global socio-cultural environment provide great opportunities for the development of a teacher who chooses professional development resources in these conditions. One of the most important conditions for improving the quality of the educational process is the transition from the level of local educational environments to the modern educational macroenvironment, formed by information and integration processes.

The concept of the integrative environment is based on the idea of integration (from lat. integratio - "connection"," completion"," restoration", integer - "whole"). In a broad sense, it means the 
combination of individual parts or functions of the system, the process of assimilation and convergence of objects. In tis study, the integration of educational environments is viewed as a new form of relation between local educational micro-environments All this determines the formation of a single macro-environment with new functions and structure. Micro-environment, as the initial level of integration, is the environment of individual educational organizations. It includes nano-environments of individual teachers, classrooms and laboratories, departments, academic associations, and structural units of educational organizations. Meso-environments have various aspects:

- meso-environment of general, professional and additional education;

- meso-environment of secondary vocational and higher education;

- regional educational meso-environment that integrate microenvironment at the level of separate regions;

- meso-environment of educational associations and holdings.

Macro-environment is integrative, and brings together the microand meso-environments. Its very concept significantly complements the information educational environment that make a global network. The macro-environment is the integrative environment of the highest level, connecting the environments of different subordinate levels. The integrative environment is marked by the systemic effect, manifested through the interaction of a set of microenvironments as structural components of the macro-environment They can not reproduce the quality of the system as a whole by themselves. This environment provides the teacher with a set of alternative opportunities to choose strategies for the development of self-efficacy.

The theoretical analysis shows the need to study the features of the development of vocational teachers' self-efficacy on the basis of meaning pedagogy and in the transformational conditions of modern integrative educational macro-environment.

\section{Materials and methods}

The leading approach to the studied problem is the integrativesystemic approach. It allows considering the development of selfefficacy on the basis of meaning pedagogy in an integrative environment.

I. A. Zimnyaya describes integrative-systemic approach as a holistic representation of a set of objects, phenomena, and processes, united by a commonality of at least one of the characteristics, resulting in the creation of new qualities of the system. Integrative-systemic approach as a set of methods and techniques is a methodological approach that orients subjects to the integral unification (integration) of any components in solving strategic and tactical problems of education and science (M. S. Pak). Its essence is integration as a combination of previously separated homogeneous and heterogeneous components. This approach allows a holistic and systematic representation of a multidimensional object. The focus of the considered approach is to implement the object as a system and a set of its tools. The bases of integration are: ontological (dialectical unity of whole and part, general and separate), epistemological (synthetic tendencies in cognition), social, and practical preconditions.

From the standpoint of the integrative-systemic approach, the integrative environment is a single system, and the properties of the whole can't be reduced to the sum of the properties of its elements. In this sense, the integrative environment is characterized by the property of integrativity - the presence of professional and developmental factors as new qualities of the environment, typical for this one only. These qualities are determined by the relations of the set of micro-environments as structural components of the macro-environment. Here, the property of the emergence of the environment is manifested. Integrativity, being the most important characteristic of the environment, determines its complementary properties of multidimensionality and unity.

\subsection{Research methods}

To solve the tasks and to confirm the hypotheses, the authors used the set of research methods that complement each other, which ensures the reliability of the study and the validity of the obtained results. They are the following:

- theoretical methods (comparative analysis and synthesis of philosophical, psychological and pedagogical scientific literature, legal documents in innovative development of education; conceptualization, classification, systematization, comparison, theoretical generalization of research results, the analogue method);

- empirical methods (testing, study of performance, analysis, and generalization of development practices);

- statistical methods (quantitative and qualitative processing of experimental data, comparative analysis, methods of mathematical statistics)

The study used a methodology of finding out the level of selfefficacy (the level was determined by a modified test of lifepurpose orientations by A. N. Leont'ev).

\subsection{The experimental base of research}

The pilot study of the teachers' self-efficacy involved 122 university teachers under 35 , with teaching experience ranging from 3 to 5 years. Teachers were divided into 5 groups (1 group -21 respondents, 2 group -25 respondents, 3 group -25 respondents, 4 group -27 respondents, 5 group -24 respondents).

\subsection{Stages of research}

The study of the problem was conducted in three stages.

The first (theoretical) stage included the study and theoretical and methodological analysis of scientific literature, the definition of the idea and aim of the study, the formulation of the problem, the purposes and hypotheses of the study, and the formulation of research problems. At this stage, the authors carried out the analysis and justification of the chosen scientific approaches to the pedagogical phenomena, determined the main provisions on the research problem, its conceptual and categorical apparatus, as well as the base of experimental research.

The second (diagnostic) stage was a pilot study to determine the level of formation of self-development of vocational teacher in the conditions of modern integrative educational environment.

The third (design) stage is the technology of teachers' self-efficacy development in an integrative environment. This technology is based on the tracing individual development as the routes to the future, points of bifurcation. One of the possible directions is selected while passing these points. This stage checked and refined the conclusions obtained during the experiment, summarized and systematized the results.

\section{Results}

Understanding of the meaning pedagogy as a system of attitudes, knowledge, and beliefs about the meaning of vocational and educational activities and the place of the teacher in contemporary society, and teachers' self-efficacy - as a personal trait, which manifests itself in inner conviction or confidence in their own professional and pedagogical actions, the following components of self-efficacy in integrative environment were defined: - understanding the professional and pedagogical goal; - purpose of professional and pedagogical activity; - results of professional and pedagogical activity;

- "I" control locus;

- "Professional and pedagogical activity» control locus;

- meaningfullness of self-efficacy of professional and pedagogical activity as a generalized component.

The main indicators of vocational teachers' self-efficacy are: 
- availability and originality of the used methods of professional and pedagogical activity, presenting educational material, forms of communication, and methods of educational influence on students; - acting "off the cuff", going beyond the instructions, considering the educational material in a non-standard, unexpected aspect; - extensive use of intuition, allowing to see the way to solve the pedagogical problem; propensity to improvisation and impromptu in teaching;

- the activity focused not on submission to a pedagogical situation, but on its purposeful transformation;

- passion for the process of professional activity;

- the ability not to lose the incentive to search for new optimal solutions in the pedagogical situation after pedagogical fails;
- the ability to progressive reflection and synthesis (bonding sensitive-perceptual and verbal-conceptual reflection of the situation), which helps to anticipate the unexpected failures and to prevent them.

The result of a pilot study is the determined levels of formedness of self-development of vocational teachers in the conditions of modern integrative educational environment.

The data obtained in the study were summarized in the table, acting as a set of components of teachers' self-efficacy and the general indicator of self-efficacy of professional and pedagogical activity (Table.1.).

Table 1: Components of teachers' self-efficacy in modern integrative environment

\begin{tabular}{|c|c|c|c|c|c|c|c|}
\hline \multirow[t]{2}{*}{ Components of self-efficacy } & \multicolumn{6}{|c|}{ Respondents - teachers } & \multirow[t]{2}{*}{ Average index } \\
\hline & Group 1 & Group 2 & Group 3 & Group 4 & Group 5 & Levels & \\
\hline $\begin{array}{l}\text { 1. Understanding the professional and } \\
\text { pedagogical goal; }\end{array}$ & 40 & 42 & 39 & 35 & 36 & $\mathrm{~B}$ & $38,4 / 42$ \\
\hline Average value \pm St. dev. & $\begin{array}{l}32,90 \pm \\
5.92\end{array}$ & $\begin{array}{c}29,38 \pm \\
6.24\end{array}$ & $\begin{array}{l}32,90 \pm \\
5.92\end{array}$ & $\begin{array}{c}29,38 \pm \\
6.24\end{array}$ & $\begin{array}{c}29,38 \pm \\
6.24\end{array}$ & & \\
\hline Value difference & $+7,1$ & +12.62 & +6.1 & $+5,62$ & $+6,62$ & & \\
\hline $\begin{array}{l}\text { 2. Purpose of professional and pedagogical } \\
\text { activity }\end{array}$ & 30 & 42 & 34 & 24 & 25 & BAv & $31 / 42$ \\
\hline Average value \pm St. dev & $\begin{array}{c}31,09 \pm \\
4.44\end{array}$ & $\begin{array}{c}28,80 \pm \\
6.14\end{array}$ & $\begin{array}{c}31,09 \pm \\
4.44\end{array}$ & $\begin{array}{c}28,80 \pm \\
6.14\end{array}$ & $\begin{array}{c}28,80 \pm \\
6.14\end{array}$ & & \\
\hline Value difference & -1.09 & $+13,2$ & +2.81 & $-4,8$ & -3.8 & & \\
\hline $\begin{array}{l}\text { 3. Results of professional and pedagogical } \\
\text { activity; }\end{array}$ & 29 & 33 & 24 & 23 & 31 & $\mathrm{BAv}$ & $28 / 35$ \\
\hline Average value \pm St. dev. & $\begin{array}{l}25,46 \pm \\
4.30\end{array}$ & $\begin{array}{c}23,30 \pm \\
4.95\end{array}$ & $\begin{array}{c}25,46 \pm \\
4.30\end{array}$ & $\begin{array}{c}23,30 \pm \\
4.95\end{array}$ & $\begin{array}{l}23,30 \pm \\
4.95\end{array}$ & & \\
\hline Value difference & +3.54 & +9.7 & $-1,46$ & -0.3 & +7.7 & & \\
\hline 4. "I" control locus & 21 & 28 & 25 & 14 & 27 & BAv & $23 / 28$ \\
\hline Average value \pm St. dev. & $\begin{array}{l}21,13 \pm \\
3.85 \\
\end{array}$ & $\begin{array}{c}18,58 \pm \\
4.30 \\
\end{array}$ & $\begin{array}{l}21,13 \pm \\
3.85 \\
\end{array}$ & $\begin{array}{c}18,58 \pm \\
4.30 \\
\end{array}$ & $\begin{array}{c}18,58 \pm \\
4.30 \\
\end{array}$ & & \\
\hline Value difference & -0.13 & $+9,42$ & +3.87 & -4.58 & +8.42 & & \\
\hline $\begin{array}{c}\text { 5. "Professional and pedagogical activity" } \\
\text { control locus; }\end{array}$ & 33 & 41 & 36 & 25 & 39 & BAv & $34,8 / 42$ \\
\hline Average value \pm St. dev. & $\begin{array}{l}30.14 \pm \\
5.80\end{array}$ & $\begin{array}{l}28.70 \pm \\
6.10 \\
\end{array}$ & $\begin{array}{c}30.14 \pm \\
5.80\end{array}$ & $\begin{array}{c}28.70 \pm \\
6.10 \\
\end{array}$ & $\begin{array}{c}28.70 \pm \\
6.10 \\
\end{array}$ & & \\
\hline Value difference & +2.86 & +12.3 & +5.86 & $-3,7$ & +10.3 & & \\
\hline $\begin{array}{l}\text { Meaningfulness of self-efficacy of profes- } \\
\text { sional and pedagogical activity }\end{array}$ & 116 & 137 & 123 & 122 & 110 & $\mathrm{BAv}$ & $121,6 / 140$ \\
\hline Average value \pm St. dev. & $103,10 \pm 15,03$ & $\begin{array}{l}95,76 \pm \\
16.54 \\
\end{array}$ & $103,10 \pm 15,03$ & $\begin{array}{l}95,76 \pm \\
16.54 \\
\end{array}$ & $\begin{array}{l}95,76 \pm \\
16.54 \\
\end{array}$ & & \\
\hline Value difference & +12.9 & +41.24 & $+19,9$ & +26.34 & $+14,24$ & & \\
\hline Total: & BAv & B & BAv & BAv & BAv & & BAv \\
\hline
\end{tabular}

\begin{tabular}{|c|c|c|c|c|c|}
\hline \multirow{2}{*}{ LEVELS } & \multicolumn{5}{|c|}{ Components of self-efficacy, $n=122$} \\
\cline { 2 - 6 } & $\begin{array}{c}\text { Understanding the } \\
\text { professional and } \\
\text { pedagogical goal, } \%\end{array}$ & $\begin{array}{c}\text { Purpose of } \\
\text { professional and } \\
\text { pedagogical } \\
\text { activity, } \%\end{array}$ & $\begin{array}{c}\text { Results } \\
\text { professional and peda- } \\
\text { gogical activity, } \%\end{array}$ & $\begin{array}{c}\text { "I" control locus, } \\
\%\end{array}$ & $\begin{array}{c}\text { Meaningfulness of self-efficacy of } \\
\text { professional and pedagogical } \\
\text { activity, \% }\end{array}$ \\
\hline High (under 80\%) & 15 & 21 & 11 & 26 & 13 \\
\hline $\begin{array}{c}\text { Above average } \\
(60-79 \%)\end{array}$ & 18 & 29 & 20 & 30 & 17 \\
\hline $\begin{array}{c}\text { Average } \\
(45-59 \%)\end{array}$ & 37 & 24 & 45 & 26 & 35 \\
\hline $\begin{array}{c}\text { Low } \\
\text { (under 44\%) }\end{array}$ & 30 & 26 & 24 & & 35 \\
\hline
\end{tabular}

The first component is understanding the professional and pedagogical goal. It reflects the presence or absence of pedagogical goals and their subject matter. This study showed a high level in university teachers: 38.4 of 42 points, which corresponds to $91.4 \%$.

The second component is the purpose of professional and pedagogical activity. It describes the perception of the subjects of the pedagogical process and its purpose. Here, it corresponds to $73.8 \%$ ( 31 and 42 points) - the level is above average.

The third component is the results of professional and pedagogical activity. It assesses the past period of activity and satisfaction with its results. In this work, it is 28 points ( 35 maximum), or $80 \%-$ above average. Indicators of this unit describe the personal responsibility of teachers for the formulation and implementation of life goals, high satisfaction with the life span, the presence of future goals, and prospects, giving purpose and meaning to life.

"I" locus control, being the fourth component, reflects the confidence in personal ability to control their lives. In this experiment it came out to be 23 points of 28 , which was $82.1 \%$ (above average). "Professional-pedagogical activity" control locus (the fifth component), showing the general worldview belief in the ability to control professional and pedagogical activity, was 34.8 and 42 (82.9\% respectively). 
The total indicator (meaningfulness of self-efficacy in professional and pedagogical activity) was $86.9 \%$ (121.6 out of 140 points) it means, a high level, -among the vocational teachers.

The reliability and validity of the research results is ensured by the consistency of the methodological and theoretical foundations of the study. A variety of information sources, comprehensive analysis of the research object, compliance with the norms and requirements for pedagogical research, the choice and implementation of a set of complementary research methods corresponding to the goal, logic and research stages also make the research results reliable. Another factors are: combination of quantitative and qualitative analysis; the representativeness of the sample of respondents and the experimental base of research; verification of the research results at various stages of experimental work, their continuity; correct statistical processing of the results and their pedagogical interpretation; positive effects of the implementation of the results.

\section{Discussion}

The results of the study indicate that the testees can be divided into two groups.

The first group of teachers with an insufficient level of selfefficacy can be described as follows:

1) life-purpose and professional and pedagogical guidelines: low indicators of meaningfulness of professional and pedagogical goal-setting; dissatisfaction with pedagogical activity and professional self-realization; low index of professional satisfaction and general pedagogical adaptation, adaptability to life; subordination to direct professional and life ties; lack of expressed ability to manage their professional activities and freely make pedagogical decisions:

2) professional qualities: lack of pedagogical creativity: lack of reflection on their professional activity; preoccupation by the pedagogical situation, propensity for conflict; rivalry and avoidance as the predominant form of communication; tension in relations with students; the tendency to disciplinary measures and formalism in teaching; dissatisfaction with their professional activities and the desire to retire as soon as possible;

3) emotional state: emotional instability, propensity for negative emotions; high level of emotional burnout leading to physical and mental exhaustion, feeling older than they are.

The second group of teachers had sufficient level of self-efficacy. They showed the following features:

1) life-purpose and professional and pedagogical guidelines: high meaningfulness of professional and pedagogical activity; satisfaction with pedagogical activity and the level of professional selfrealization; relatively high indicators of "I" control locus (I am the owner of my life) and control over life (according to test by D. A. Leont'ev); attitude to their professional activity as to the most important lifework;

2) professional qualities: high pedagogical creativity; reflection on their professional activities; desire to go beyond the single pedagogical situation, to determine how implemented their own professional plans and the limits of their capabilities are; flexibility; cooperation as the dominant form of communication with students and resolving difficult situations; an atmosphere of trust in the classroom, raising direct interest in the subject in students; the desire to continue their professional activities after reaching the retirement age;

3) emotional state: emotional stability, propensity to positive emotions; ability to obtain emotional satisfaction in pedagogical activity; low level of emotional burnout and relatively higher rates of physical and mental health, feeling younger than they are.

Comparison and analysis of both groups shows that in fact they are not just a set of some qualities and manifestations, but a certain hierarchy, the leading components of which are combined life-purpose and professional-pedagogical guidelines and selfefficacy. Apparently, that link has a common psychological basis.
In other words, the search for pedagogical purpose, and the selfefficacy imply "going beyond the immediate life (professional and pedagogical) links" (S. L. Rubinshteyn), beyond the situation and establishing their attitude to their lives and professional activities. Teachers with low self-efficacy find themselves "inside life", they are enslaved by a variety of specific circumstances and responsibilities, which makes professional work monotonous, dull, emotionally unattractive. The ones with high self-efficacy "interrupt" this routine flow of life, go beyond it. The search for the life purpose for them is also the search for ways of pedagogical creativity; it leads to the meaningfulness of life.

The life purpose is understood as the ontological significance, i.e. personal experience of the meaning of his existence, the fullness of life, the general background emotional state of the person.

The purpose of life, the purpose of existence are philosophical and spiritual problems related to the ultimate goal of existence, the purpose of mankind, of man as a biological species. It is one of the basic philosophical concepts, which is of great importance for the formation of the spiritual and moral image of a person. Value and meaning-wise attitude to the profession can and should be taught. It is extremely important to correlate the goals and objectives of the educational process of the university with the problem of life orientations of future professional teachers.

The results of the pilot study showed the tutoring support for the development of vocational teachers' self-efficacy is necessary. The paper presents the technology of developing teacher's self-efficacy in integrative environment. This technology is based on the tracing individual development as the routes to the future, points of bifurcation. One of the possible directions is selected while passing these points.

\section{Recommendations}

The development of the teacher's self-efficacy is a continuous process initiated by the integrative environment. The educational environment stimulates the development of the teacher's ability to self-improvement. Self-efficacy acts as a way of human response to the impact of the social environment and as a process of selfchange under the influence of internal contradictions. Teachers use the developing resources of educational environment for their self-development. In turn, teachers affect the educational environment: by changing and transforming it, they change personally and professionally. It is the mutual influence of the educational environment and self-development. Integrative environment acts as a multi-dimensional, ordered space and a new degree of freedom that allows increasing the efficiency of self-efficacy development. Integrative environment provides continuity both between the levels of education and in the teachers' concentric development (from low to high level). Integrative environment creates the dominant for the development of teacher's self-efficacy, determines its variable models, and its performance. This environment is a professionally developing system in its origin.

Tracing individual development of self-efficacy in the integrative environment assumes its optimum saturation by developing situations in the sequence of structural components. Variable scenarios of the teacher's self-efficacy development in the integrative environment can be fixed and expressed as a material project, or be mental, abstract, depending on the individual characteristics of teacher's personality type.

The leading principle in the design of individual trajectories of teachers' self-efficacy development is the principle of variability. It is a key feature, the ability of the integrative environment to provide the teacher with a variety of development options, a range of opportunities to choose an individual path of development of self-efficacy. The integrative environment as a variable system provides the maximum degree of individualization of the selfefficacy development.

Variability as a basis for designing individual trajectories of development is provided by: 
- the variety of ways and means of development tracing in an integrative environment;

- features of the environment, its resource potential, environmental factors, conditions, and principles;

- individualization of the development of teachers' self-efficacy;

- availability of professionally developing resources, freedom and responsibility in their choice;

- the optimal combination of self-management and tutor support of the development.

Conditions reflect the relation of the object to the surrounding phenomena, without which it can not exist; they allow using certain transformations to obtain the desired result. In contrast to the factors, conditions make up the environment, in which the process of self-development is carried out. However, the conditions may be specially created to affect self-development.

The conditions of the integrative environment refer to external circumstances that significantly affect the development of teacher's self-efficacy. These conditions may be designed in the local micro-environment of the professional educational organization for the tutor support of developing teacher's self-efficacy. These pedagogical conditions include:

- initiation of the development of teacher's self-efficacy, motivation for self-improvement, and learning the basics of selforganization;

- methodological assistance in the design of individual development trajectory of teacher's self-efficacy;

- implementation of scientific and methodological support of the development process, coordination of activities for the implementation of the development project, and ensuring the availability of professional development resources;
- organization of monitoring of the development process based on the comparison of self-diagnosis and expert assessments, generalization of the development results in the products of pedagogical creativity;

- scientific and methodological support of self-control, ensuring the continuity of self-efficacy development;

The considered development process in an integrative environment is based on the principles of variability, integrativity, openness, saturation with professional development resources, their availability, creative interaction, and complementarity of management and self-organization.

The main driving force for the development of self-efficacy is resolving the contradictions in the course of solving complex professional and pedagogical problems. The "starting mechanism" of teacher's self-efficacy development is meanings of professional and pedagogical activity. The next stage is setting the goal as a subjective image of the desired result (goal-setting here acts as design). Then, teachers carry out the performing actions to achieve the development result. The studied development process is based on self-organization and self-control over the activity, the success of which depends on the formedness of competencies responsible for self-management.

Self-efficacy development is a cyclic continuous process, designed by teachers themselves and carried out in stages in accordance with the algorithmic cycle of activity. The cycle consists of the formation of internal motivation - setting goals as a planned result (design) - performing actions - assessment of the development (reflection) - adjustment actions (see Fig.).

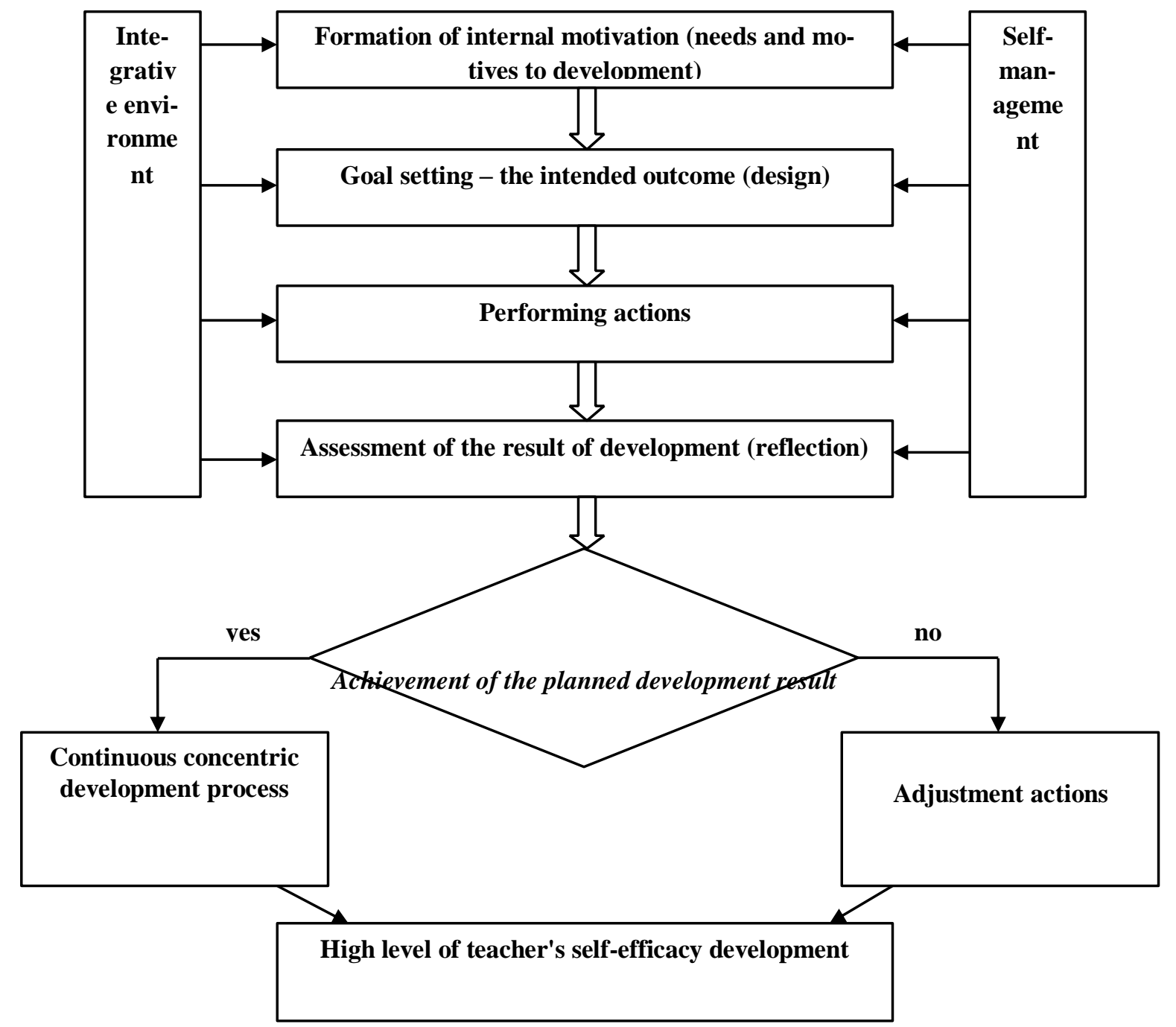

Fig1: Algorithmic cycle of teacher's self-efficacy development. 
The impact of the integrative environment on the algorithmic cycle of teacher's self-efficacy development is also considered in this study.

1. Formation of internal motivation (needs and motives to development)

Teachers with formed self-organizational competencies are able to adapt and transform the influence of the integrative environment into the development motives. Adaptation here is viewed as an internal desire for self-development. The social conditions of the integrative environment determine the needs of teachers' development, which are specified in the meanings - the drivers and driving forces of development. The integrative environment contributes to the actualization of the meanings of the self-efficacy development. The development motives can be internal and external, leading and situational. It is self-affirmation, self-actualization as teachers' ability to become what they can become; selfrealization in professional and pedagogical activity; success in the professional community, as well as socially significant motives (feeling professional duty and aptitude, responsibility, awareness of teacher's mission).

2. Goal setting - the intended outcome (design)

The integrative environment determines the requirements for the level of professional skills and the results of pedagogical activity, and initiates the goal-setting of the studied development; the goal is determined by the subject. Goal-setting is carried out by the teacher based on personal development motives and with due account to the social order of the integrative environment.

3. Performing actions.

The integrative environment determines the content of norms and principles of activity, as well as the result of teacher's development. The integrative environment, possessing variability, openness and plasticity, significantly enhances the professional and developmental impact, in comparison with individual microenvironments. The variability of professional development resources provides for the construction of an individual trajectory of teacher's self-efficacy development and allows this process to be carried out on the basis of an alternative choice with the greatest efficiency in order to achieve the planned results.

4. Evaluation of the result of self-efficacy development (reflection).

The integrative environment provides the feedback to the development on the basis of continuous monitoring and recording the individual indicators in accordance with the criteria for the selfefficacy development. Comparative evaluation of the development results is carried out based on personal (internal) and external criteria for compliance with the results of the goal. External evaluation criteria are established by the integrative environment.

The priority tasks of scientific and methodological support for the development of teacher's self-efficacy in an integrative environment are the following:
- initiation of the development process;

- providing consulting assistance at the level of the local microenvironment of professional educational organization in the design and implementation of the individual development trajectory on the basis of variable capabilities of the integrative environment;

- implementation of diagnostics and analysis of the results of the studied development.

Thus, scientific and methodological support for teacher's selfefficacy development allows:

- aiming the teacher on the continuity of development;

- carrying out the design and implementation of an individual development trajectory;

- identifying the level of teacher's self-efficacy development;

- conducting an objective analysis and self-analysis of selfefficacy development to determine its dynamics;

- summarizing the positive experience of the development and ensuring its distribution.

According to the results of the study, the main stages of tracing individual development of teachers' self-efficacy are determined with due regard to the cycle of activity.

The diagnostic stage carried out the analysis of the socio-cultural situation, determined the qualitative characteristics of the integrative environment, the leading motives, and the degree of willingness for the development of self-efficacy, as well as the initial level of development of teacher's self-efficacy.

The prognostic stage elaborated a project of future activities, including the concept of self-efficacy development and a strategy for its implementation (goals and objectives, resources and conditions, expected results, step-by-step plan for the implementation of planned actions). At this stage, it is important to predict the possible directions of development based on the probabilistic scenarios and the choice of the best option.

The practical stage carried out the executive actions to implement the developed project of development of teacher's self-efficacy.

The reflexive stage assesses the results of the self-efficacy development according to internal and external criteria. The products of pedagogical activity, confirming the positive dynamics of the results of the development, are analyzed. Products of pedagogical activity are certificates and diplomas of participation in competitions, research and practice conferences, seminars, festivals, forums; publications, projects, pedagogical development; documents on training, broadcasting the experience of practical results of professional and educational activities, and other achievements. The reflexive stage of self-efficacy development includes making adjustment actions and setting prospects of further development. The study identified ways to minimize the development of vocational teacher's self-efficacy in an integrative environment (Tab. 2).

Table 2: Potential risks of teacher's self-efficacy development in an integrative environment and ways to minimize them

\begin{tabular}{|l|l|}
\hline Risks of self-efficacy development & Ways to minimize the risks of self-efficacy development \\
\hline 1. Quasi-reality of virtual space. & $\begin{array}{l}\text { 1. Strengthening role of real space as opposed to the virtual one of the integrative educa- } \\
\text { tional environment. } \\
\text { The interactive impact of the integrative educational environment on the development of } \\
\text { self-efficacy allows replacing the mental interpretation of the real impact. }\end{array}$ \\
\hline $\begin{array}{l}\text { 2. "Clip thinking" as a vector in the development of rela- } \\
\text { tions between specialist and information. } \\
\text { The use of fragmentary information (often unsystematic), } \\
\text { and no need to analyze voluminous texts. }\end{array}$ & $\begin{array}{l}\text { 2. Development of skills of the situational analysis , integral perception of the increasing } \\
\text { Establishment of logically interconnected series of events from general to particular and } \\
\text { from particular to general. }\end{array}$ \\
\hline $\begin{array}{l}\text { 3. Potential informational hazard of the Internet resources. } \\
\text { tive impact of the environment on the development of per- } \\
\text { sonal traits of the teacher, determining the process of effi- } \\
\text { cient communication. }\end{array}$ & $\begin{array}{l}\text { Teachers' participation in live scientific conferences, professional competitions, seminars, } \\
\text { festivals, and other scientific and methodological activities. }\end{array}$ \\
\hline $\begin{array}{l}\text { 5. Unreasonable and excessive use of multimedia resources } \\
\text { and information and communication technologies in the } \\
\text { educational process. }\end{array}$ & $\begin{array}{l}\text { 5. The selection of training forms, methods and technologies should be carried out depend- } \\
\text { ing on the priority of educational goals, the specifics of the content of educational material, } \\
\text { the level of development and preparedness of students, their motivation, and scope of } \\
\text { interests. }\end{array}$ \\
\hline
\end{tabular}


An important role in minimizing the identified risks of development of teacher's self-efficacy is played by the tutor support for the implementation of personal development strategy. The task of the tutor are to create conditions for the development of teacher's self-efficacy at the micro-environment level, to assist in the construction and implementation of an individual developmental trajectory, and to monitor this process as an important ensuring mechanism. The tutor assists in the successful integration of teachers into the modern integrative environment.

\section{Conclusion}

Thus, the study reveals the essence, content and structural components of self-efficacy in the conditions of modern integrative environment in terms of meaning pedagogy. The results of the pilot study showed the need for targeted development of vocational teachers' self-efficacy. In this regard, the authors develop the technology of development of teachers' self-efficiency in an integrative environment.

The novelty of the research results in comparison with the previously published materials is that for the first time, the teachers' self-efficacy is considered as a personal trait based on the meaning of professional and pedagogical activity in the conditions of integration of educational environments. The research results define new vectors of self-efficacy development on the basis of lifeoriented guidelines; significantly expand the theoretical understanding of development and self-development of teachers in the modern integrative environment.

The results of the study are reproducible, and are of practical value for the organization of tutor support for the development of teachers' self-efficacy. They can also be used in systems of continuous education.

The process of research provoked new questions and problems that need to be addressed. It is necessary to continue research on the development and testing of a model for the development of teachers' self-efficacy on the basis of meaning pedagogy and in an integrative environment, to develop and implement the monitoring over the teachers' self-efficacy development in educational practice.

\section{References}

[1] Bandura, A. (2000). Theory of social acquisition [Teoriya sotsial'nogo naucheniya]. Saint Petersburg: Evraziya, 320p.

[2] Baybanova, F.A. (2014). Dynamic features of future teachers' selfefficacy [Dinamicheskie osobennosti lichnostnoy samoeffektivnosti budushchego pedagoga]. Fundamental'nye issledovaniya, 11, 27192723.

[3] Davoudi SMM, Fartash K, Venera G. Zakirova, Asiya M. Belyalova, Rashad A. Kurbanov, Anna V. Boiarchuk, Zhanna M. Sizova (2018). Testing the Mediating Role of Open Innovation on the Relationship between Intellectual Property Rights and Organizational Performance: A Case of Science and Technology Park, EURASIA Journal of Mathematics Science and Technology Education, 14(4), 1359-1369.

[4] Fartash K., Davoudi, S.M.M., Tatiana A. Baklashova, Natalia V. Svechnikova 4, Yulia V. Nikolaeva, Svetlana A. Grimalskaya (2018). The Impact of Technology Acquisition \& Exploitation on Organizational Innovation and Organizational Performance in Knowledge-Intensive Organizations, EURASIA Journal of Mathematics Science and Technology Education, 14(4), 1497-1507.

[5] Frankl, V. (1990). Man seeking meaning [Chelovek v poiskakh smysla]. Moscow: Progress, 368p.

[6] Gonchar, S.N. \& Klimenko, I.V. (2015). Self-efficacy as a significant quality of teacher's personality as the initiator of the continuous educational movement [Samoeffektivnost' kak znachimoe kachestvo lichnosti pedagoga - initsiatora nepreryvnogo obrazovatel'nogo dvizheniya]. Vestnik Saratovskogo oblastnogo instituta razvitiya obrazovaniya, 4, 123-129.
[7] Key competences and new literacy [Klyuchevye kompetentsii i novaya gramotnost'] (n.d.). Natsional'nyy issledovatel'skiy universitet «Vysshaya shkola ekonomiki». URL: https://ioe.hse.ru/21 skills.

[8] Kuz'mina, N.V. (1990). Professionalism of the personality of teacher and master of industrial training [Professionalizm lichnosti prepodavatelya i mastera proizvodstvennogo obucheniya]. Moscow: Vysshaya shkola.

[9] Leont'ev, A.N. (1983). Selected psychological works: in 2 volumes [Izbrannye psikhologicheskie proizvedeniya: v 2-kh t.]. V. 1. Moscow: Pedagogika, 392p.

[10] Ozhegov, S.I. (2005). Dictionary of Russian [Slovar' russkogo yazyka]. Ed. Prof. Skvortsova, L.I. Moscow: OOO «Izdatel'skiy dom ONIKS 21 vek»: OOO «Izdatel'stvo «Mir i Obrazovanie», $723 p$.

[11] Pak, M.S. (1991). Theoretical bases of an integrative approach in the process of chemical training of vocational school students [Teoreticheskie osnovy integrativnogo podkhoda $\mathrm{v}$ protsesse khimicheskoy podgotovki uchashchikhsya proftekhuchilishch]. Extended abstract of Doctoral Dissertation. Leningrad.

[12] Rubinshteyn, S.L. (1997). Selected philosophical and psychological works. Fundamentals of ontology, logic and psychology [Izbrannye filosofsko-psikhologicheskie trudy. Osnovy ontologii, logiki i psikhologii]. Moscow: Nauka, 463p.

[13] Rubinshteyn, S.L. (2007). Fundamentals of general psychology [Osnovy obshchey psikhologii]. Saint Petersburg: Piter, 713p.

[14] Taştan, S.B., Davoudi, S.M.M., Masalimova, A.R., Bersanov, A.S., Kurbanov, R.A., Boiarchuk, A.V., Pavlushin, A.A.(2018). The Impacts of Teacher's Efficacy and Motivation on Student's Academic Achievement in Science Education among Secondary and High School Students, EURASIA Journal of Mathematics Science and Technology Education, 14(6), 2353-2366.

[15] Timofeeva, T.V. (2015). Professional self-efficacy: semantic analysis of the essence and content [Professional'naya samoeffektivnost' lichnosti: semanticheskiy analiz sushchnosti i soderzhaniya]. In collected works: Mirovoe kul'turno-yazykovoe i politicheskoe prostranstvo: innovatsii v kommunikatsii.

[16] Vygotsky, L.S. (1996). Pedagogical psychology [Pedagogicheskaya psikhologiya]. Moscow: Pedagogika-Press, 536p.

[17] Zimnyaya, I.A. \& Zemtsova, E.V. (2008). Integrative approach to assessing the unified socio-professional competence of university graduates [Integrativnyy podkhod $\mathrm{k}$ otsenke edinoy sotsial'noprofessional'noy kompetentnosti vypusknikov vuzov]. Vysshee obrazovanie segodnya, 5, 14-19. 